\title{
MANAGEMENT OF PATIENTS \\ WITH ARTERIAL HYPERTENSION AFTER IMPLANTATION OF CARDIAC PACEMAKER
}

\section{Deriyenko T. A., Tykhonova T. M.}

\section{INTRODUCTION}

Cardiac pacemaker is a leading method of treatment in patients with bradysystolic rhythm and conduction disorders ${ }^{1,2}$. Implantation of pacemaker - improves the quality of patients life, decreases mortality and hospitalization rates ${ }^{3,4}$.

Hypertension $(\mathrm{AH})$ is a leading problem in modern cardiology, which is associated with its prevalence and complications ${ }^{5,6}$. Overall, the prevalence of hypertension is in the range of $30-45 \%$ of the total population with a sharp increase in the age $\mathrm{e}^{7} \mathrm{AH}$ is the most common concomitant pathology in

1 Шанина, И.В., Волков, Д.Е., Бойко, В.В., Яблучанский, Н.И. Постоянная электрокардиостимуляция и медикаментозное сопровождение пациентов. Серце I Судини. 2014. № 2(46). С. 91-95.

${ }^{2}$ Brignole, M. et al.ESC Guidelines on cardiac pacing and cardiac resynchronization therapy.EuropeanHeartJournal. 2013. № 34(29). С. 2281-2329.

3 Бокерия, Л., Ревишвили, А., Голицин, С. Всероссийское научное общество специалистов по клинической электрофизиологии, аритмологии и кардиостимуляции (BНОА). Клинические рекомендации по проведению электрофизиологических исследований, катетерной абляции и применению имплантированных антиаритмических устройств. НоваяРедакция. 2013.

${ }^{4}$ Tracy, C., Epstein, A., Darbar, D., DiMarco, J., Dunbar, S., Estes, N. et al. 2012 ACCF/AHA/HRS Focused Update of the 2008 Guidelines for Device-Based Therapy of Cardiac Rhythm Abnormalities: A Report of the American College of Cardiology Foundation/American Heart Association Task Force on Practice Guidelines and the Heart Rhythm Society. Circulation: 126(14). 2012: 1784-1800.

${ }^{5}$ Buess, D., Giezendanner, S., Henny-fullin, K., Handschin, A., Tschudi, P., Martina, B. et al. Compliance with ESH/ESC guidelines for arterial hypertension in Swiss primary care. Journal Of Hypertension. 34. 2016: e73-e74.

${ }^{6}$ Stefanadis, S. Management of arterial hypertension: from no treatment to renal denervation. HellenicJCardiol: 2015. 8-277.

${ }^{7}$ Buess, D., Giezendanner, S., Henny-fullin, K., Handschin, A., Tschudi, P., Martina, B. et al. Compliance with ESH/ESC guidelines for arterial hypertension in Swiss primary care. Journal Of Hypertension. 34. 2016: e73-e74.Stefanadis, S. Management of arterial hypertension: from no treatment to renal denervation. Hellenic J Cardiol: 2015. 8-277. 
patients with implanted pacemakers, which significantly affects in the control of $\mathrm{BP}^{8}$.

Implantation of the cardiac pacemaker synchronizes the contraction of the cardiac chambers, improves the pumping function of the heart, which leads to changes in hemodynamic parameters, namely, increases the ejection fraction of the left ventricle (EF LV) thereby causing instability of systolic and diastolic blood pressure (SBP and DBP), as a result of the progression of hypertension. Control of hemodynamic parameters at the observation stages is one of the main tasks for evaluating the efficacy of cardiac pacemaker with its medical support. This group of patients needs constant monitoring and correction of drug therapy. A number of studies show that patients with implanted pacemaker require modification of drug therapy ${ }^{9}$, despite the fact that this problem has not been sufficiently studied.

Implantation of pacemaker does not reduce the need for drug therapy in patients with hypertension and adds new opportunities for complications such as, for example, induced arrhythmias ${ }^{10}$. Implantation of cardiac pacemaker significantly enhances the possibilities of drug therapy, but at the same time, there are additional requirements for outpatient follow-up.

The importance of patient management after implantation of an antiarrhythmic device is difficult to overestimate. Modern pacemaker is a sophisticated programmable device with many therapeutic and diagnostic functions, so it requires regular checking and adjustment ${ }^{11,12}$. When it comes to observing patients with implanted pacemaker, it means evaluating the performance of the entire stimulation system, not just one device. Since the stimulation system consists of 3 main units: the pacemaker, electrodes and the heart of the patient, the control should assess the status of all these units $^{13}$.

${ }^{8}$ Лазебник, Л., \& Комисаренко, И. Артериальная гипертония и сопутствующие заболевания. В Мире Лекарств. 2000. № 3. С. 20-26.

9 Elango K., Curtis A.B..Cardiac implantable electrical devices in women ClinCardiol.Epub.: 2018. 41(2). 232-238.

${ }^{10}$ Шанина, И.В., Волков, Д.Е., Бойко, В.В., Яблучанский, Н.И. Постоянная электрокардиостимуляция и медикаментозное сопровождение пациентов. Серце I Судини. 2014. № 2(46). С. 91-95.

${ }^{11}$ Peinado, R., Ruiz-Mateas, F., Izquierdo, M., Arana, E., Robledo, M., Arias, M. et al. Cardiac Arrhythmias and Pacing 2015: A Selection of Topical Issues. Revista Española De Cardiología (English Edition): 2016. 69(2). C. 167-175.

12 Wilkoff BL, et al. 2015 HRS/EHRA/APHRS/SOLAECE expert consensus statement on optimal implantable cardioverter-defibrillator programming and testing. EP Europace: 2017. 19(4). C. 580.

${ }^{13}$ Kusumoto, F., Goldschlager, N. Cardiac pacing for the clinician. New York : Springer: 2008. C. 30-742. 
Implanted pacemaker significantly expand the possibilities of drug therapy, but at the same time, additional requirements appear for outpatient follow-up of patients after the implantation ${ }^{14,15,16}$. However, it is necessary to take into account the effect of drugs on the threshold of electrocardiostimulation, which can result in serious hemodynamic disorders. The threshold of electrocardiostimulation is increased by potassium, $\beta$-blockers, calcium channel blockers, quinidine, aymalin, isoprene, isadrine, and prednisone, but norepinephrine, ephedrine - reduce.

\section{Materials and methods of the research}

The research involved 119 patients (62 men and 57 women) at the age of $69.5 \pm 11.6$ years. All patients were implanted with pacemakers and were stimulated in the following way: $\mathrm{DDD}$ (dual chamber demand pacing) (32 patients), DDDR (dual-chamber, rate-modulated) (46 patients), VVI (ventricular demand pacing) (35 patients), VVIR (ventricular ratemodulated) (6 patients). According to the recommendations of the European Association of Cardiologists, 11 patients (9\%) had 1st degree hypertension, 64 patients $(54 \%)$ had 2 nd degree hypertension, and 44 patients $(37 \%)$ suffered from 3rd degree hypertension.

The inclusion criterions were the presence of $\mathrm{AH}$ and indications for implantation of the cardiac pacemaker. Patients less than 40 years, with the presence of concomitant stable angina IV, chronic heart failure (CHF) IV functional class (FC) before the implantation of pacemaker, with right ventricular and / or left ventricular (LV) stimulation less than 50\% during the year of follow-up, were excluded from the study.

Patient studies were performed using a set of clinical and instrumental methods. All patients underwent Echocardiogram, electrocardiogram (ECG), measured blood pressure and pacemaker parameters.

To measure heart rate (HR) and to determine abnormalities of conduction disorders of the heart a 12-channel ECG was recorded. ECG registration was performed after a 10-minute rest period and not earlier than 2 hours after meal.

${ }^{14}$ Coma Samartín, R., Ruiz Mateas, F., Fidalgo Andrés, M., Leal delOjo González, J., Pérez Álvarez, L. Spanish Pacemaker Registry. 10th Official Report of the Spanish Society of Cardiology Working Group on Cardiac Pacing (2012). Revista Española De Cardiología (English Edition): 2013. 66(12). C. 72-972.

${ }^{15}$ Naqvi, T. The next 10 years in cardiac pacing. Expert Review Of Cardiovascular Therapy: 2013). 11(7). С. 807-809.

16 Бокерия, Л., Ревишвили, А., Гордеев, О. Клинические рекомендации по применению электрокардиостимуляторов. Вестник Аритмологии. 2009. № 58. C. 60-79. 
The echocardiogram was performed in the patient's position on the left side, while breathing in high breaths in accordance with the American Society of Echocardiography criteria ${ }^{17}$ The sizes of left atrium (LA), right atrium (RA), right ventricular (RV), left ventricular posterior wall thickness (LVPWd), thickness of the interventricular septum (IVS). Calculation of the end diastolic volume (EDV) and end systolic volume (ESV) was performed using the Teichholz formula.

Measurement of blood pressure was performed by the method of Korotkov. Measurements were performed three times at 2-minute intervals on two hands, after which the average SBP and DBP were calculated.

The registration and analysis of the stimulation parameters was performed in the patient's lying position, with breathing comfort, using the programmers of the companies of the manufacturers of the pacemaker: Medtronic 2090 ver 2.6 (Medtronic, USA, 2006), Merlin Model 3650 (St. Jude Medical, USA, 2013), Boston Scientific Zoom Latitude Model 3120 (Boston Scientific, USA, 2012), Sorin Orchestra Plus Programmer (Sorin Group, Italy, 2012). Stimulation parameters were determined by stimulation mode, percentage of stimulation of RA, RV and LV (\%), baseline stimulation frequency (beats / min), impedance (om), amplitude (B) and duration (ms) of the stimulus of the RV and LV electrodes, stimulated and detected, AV delay (ms). Measurement accuracy - $1 \mathrm{~ms}$.

Treatment of patients with implanted cardiac pacemaker was based on the Recommendations for the Implantation of Electrical Devices for Rhythm and Conductivity Disorders of the Ukrainian Association of Cardiologists ${ }^{18}$ and in accordance with the recommendations of the European Society of Cardiology for the Implantation of Cardiac Pacing and Cardiac Resynchronization Therapy ${ }^{19}$. The treatment of hypertension was performed in accordance with the recommendations of the Association of Cardiologists of Ukraine for the Prevention and Treatment ofArterial Hypertension ${ }^{20}$ and

${ }^{17}$ Lang, R., Bierig, M., Devereux, R., Flachskampf, F., Foster, E., Pellikka, P. et al. Recommendations for Chamber Quantification: A Report from the American Society of Echocardiography's Guidelines and Standards Committee and the Chamber Quantification Writing Group, Developed in Conjunction with the European Association of Echocardiography, a Branch of the European Society of Cardiology. Journal Of The American Society Of Echocardiography. 2005. № 18(12). C. 1440-1463.

${ }^{18}$ Janson, C., Shah, M. Supraventricular Tachycardia in Adult Congenital Heart Disease. Cardiac Electrophysiology Clinics: 2017. № 9(2). C. 189-211.

${ }^{19}$ Brignole, M. et al. ESC Guidelines on cardiac pacing and cardiac resynchronization therapy. European Heart Journal. 2013. № 34(29). С. 2281-2329.

${ }_{20}$ Рекомендації Української Асоціації Кардіологів 3 профілактики та лікування артеріальної гіпертензії-2011 рік. WebCardio.org. (2011). URL: http://www.webcardio.org/ rekomendatsiji-ukrajinsjkoji-asotsiatsiji-kardiologhiv--z-profilaktiki-ta-likuvannya-arterialjnojighipertenziji--2011rik.aspx. 
in accordance with clinical guidelines for hypertension of the European Society of Hypertension and Society of Cardiologists ${ }^{21}$.

Drug therapy for hypertension included: angiotensin converting enzyme (ACE) inhibitors, angiotensin II receptor blockers (BRA), diuretics, betablockers (BAB), slow calcium channel blockers (CCB). The target dose for warfarin was $5 \mathrm{mg}$ (initial - $2.5 \mathrm{mg}$, maximum - $10 \mathrm{mg}$ ), for dabigatranetexilate $-220 \mathrm{mg}$, for rivaroxaban $-20 \mathrm{mg}$, for acetylsalicylic acid $-75 \mathrm{mg}$, for clopidogrel $-75 \mathrm{mg}$, for amiodarone - $200 \mathrm{mg}$ (initial $100 \mathrm{mg}$, maximum $-600 \mathrm{mg}$ ), for furosemide $-40 \mathrm{mg}$ (initial $-20 \mathrm{mg}$, maximum - $160 \mathrm{mg}$ ), for torasemide $-10 \mathrm{mg}$ (initial $-5 \mathrm{mg}$, maximum $20 \mathrm{mg}$ ), for hydrochlorothiazide $25 \mathrm{mg}$ (initial $-12.5 \mathrm{mg}$, maximum $50 \mathrm{mg}$ ), for bisoprolol $-5 \mathrm{mg}$ (initial $-2.5 \mathrm{mg}$, maximum $-10 \mathrm{mg}$ ), for metoprolol - $100 \mathrm{mg}$ (initial $-50 \mathrm{mg}$, max. $-150 \mathrm{mg}$ ), for carvedilol $12.5 \mathrm{mg}$ (initial $-6.25 \mathrm{mg}$, maximum $-25 \mathrm{mg}$ ), for nebivolol $-5 \mathrm{mg}$ (initial - $2.5 \mathrm{mg}$, maximum - $10 \mathrm{mg}$ ), for amlodipine $-5 \mathrm{mg}$ (maximum $10 \mathrm{mg}$ ), for nifedipine $-60 \mathrm{mg}$ (initial $-30 \mathrm{mg}$, maximum $-90 \mathrm{mg}$ ), for verapamil $-80 \mathrm{mg}$ (initial $-40 \mathrm{mg}$, maximum - $120 \mathrm{mg}$ ), for enalapril $10 \mathrm{mg}$ (initial $-5 \mathrm{mg}$, maximum - $20 \mathrm{mg}$ ), for lisinopril - $10 \mathrm{mg}$ (initial $5 \mathrm{mg}$, maximum $-20 \mathrm{mg}$ ), for ramipril $-5 \mathrm{mg}$ (initial $-2.5 \mathrm{mg}$, maximum $10 \mathrm{mg}$ ), for losartan $-50 \mathrm{mg}$ (initially $-25 \mathrm{mg}$, maximum $-100 \mathrm{mg}$ ) for candesartan $8 \mathrm{mg}$ (initially $4 \mathrm{mg}$, maximum $16 \mathrm{mg}$ ), atorvastatin and sivastatin $20 \mathrm{mg}$ (initial $10 \mathrm{mg}$, maximum $40 \mathrm{mg}$ ). Before the implantation, in the early postoperative (3-5 days), at the semi-annual and annual stages after implantation, frequency of administration and dose ratios of the drugs were determined depending on the degree of hypertension. Dose coefficients at the study stages were calculated as their average values for the respective stages, attributed to the average therapeutic doses.

According to the classification of hypertension of the Ukrainian Association of Cardiologists ${ }^{22}$, all patients were divided into 3 groups depending on the degree of $\mathrm{AH}-1,2$ and 3 .

In the groups at the stages of the study was determined the following characteristics: gender (male, female), age, coronary heart disease:

${ }^{21}$ Mancia, G., Fagard, R., Narkiewicz, K., Redán, J., Zanchetti, A., Böhm, M. et al. 2013 Practice guidelines for the management of arterial hypertension of the European Society of Hypertension (ESH) and the European Society of Cardiology (ESC). Journal Of Hypertension. 2013. № 31(10). C. 1925-1938.

${ }^{22}$ Tracy, C., Epstein, A., Darbar, D., DiMarco, J., Dunbar, S., Estes, N. et al. 2012 ACCF/AHA/HRS Focused Update of the 2008 Guidelines for Device-Based Therapy of Cardiac Rhythm Abnormalities: A Report of the American College of Cardiology Foundation/American Heart Association Task Force on Practice Guidelines and the Heart Rhythm Society. Circulation. 2012. № 126(14). C. 72-959. 
postinfarctioncardiosclerosis, angina pectoris (I, II, III and IV); stage AH (I, II, III); stage CHF (I, IIA, IIB, III); DM type (I, II); arterial fibrillation (AF) (paroxysmal and persistent, permanent, first emergent, long-term persistent); SBP and DBP; heart rate (HR); the sizes of LA, RA, RV, LVPWd, thickness of the IVS, EDV, ESV; pacemaker parameters (base frequency of stimulation, percentage of stimulation of $L V$ and $R V$, impedance of LV and RV electrodes, amplitude of RV and LV electrodes, detected and stimulated AV delay); prescribing frequency and dose ratios of medications.

Patients were examined at the 4 stages: before implantation of the cardiac pacemaker, in the early postoperative period (3-5 days), 6 months, and 1 year after the implantation of the pacemaker.

The obtained data were processed after the database was created in Microsoft Excel using Statistica 9.For each of the continuous values, at their normal or abnormal distribution, either the mean (M) and the standard deviation (SD), or the median and the interquartile interval, respectively, were determined. Quantitative indicators are presented as $\mathrm{n}(\%)$. When comparing groups of patients according to the main indicators (depending on the type of distribution of indicators that were analyzed) used the unpaired Student's T-criterion or Mann-Whitney U-criterion. The results were considered reliable at significance levels of $\mathrm{p}<0.05$ and $\mathrm{p}<0.01$.

ANOVA method was used to establish differences between the three factors. Two-way Fisher exactte stand $\chi^{2}$ criteri on were used to analyze the $2 \times 2$ conjugation tables. Potential factors that may be associated with achieving control of blood pressure were first identified by univariate logregression analysis and then by multivariate log-regression analysis. The odds ratio, the interquartile interval were determined, and the Waldmetric was used to compare the force of influence. The results were considered reliable at significance levels of $\mathrm{p}<0.05$.

\section{Clinical presentation of the studied groups}

Before the implantation 1degree $\mathrm{AH}$ was found in 9\%, 2 degree $\mathrm{AH}$ - in $54 \%, 3$ degree $\mathrm{AH}-$ in 37\%. The average age of patients did not differ significantly $(\mathrm{p}>0.05)$ in all hypertension groups. Hypertension degree 1 was more common in men than in women, while hypertension of the 2 nd degree was observed in both sexes with almost identical frequency. Hypertension degree 3 was more often among women.

Hypertension degree 1 was more common in patients with paroxysmal and persistent form of atrial fibrillation, CHF stage I; hypertension degree 2 was more common for patients with coronary artery disease, permanent form of AF, CHF stage II A and hypertension stage II; hypertension degree 3 was 
typical for patients with postinfarction cardiosclerosis, type II diabetes and CHF stage IIB.

The high incidence of moderate to severe hypertension prior to pacemaker implantation confirms the need for more rigorous control of arterial pressure and optimized medical management for patients with implanted pacemakers.

Initially, the heart rate was below the standard in all groups of hypertension. After patients were implanted with pacemakers, their heart rate has returned to normal without any significant difference between the groups. After the enhancement of antihypertensive therapy, initially high systolic pressure at the annual monitoring period decreased and reached the standard high values in the groups of hypertension degree 1 and 2 . In the group of AH 3 degree the initially high systolic pressure decreased at the annual monitoring stage, however, without reaching the optimal pressure values. Thanks to the optimization of antihypertensive therapy, the initially high diastolic pressure decreased and reached the optimal values at the stage of the annual monitoring.

End-diastolic volume and end-systolic volume of the left ventricle exceeded the standard values in all groups of hypertension before pacemaker implantation, but there was a tendency of decrease after implantation which significantly improves hemodynamic function (in the group of AH 1st. $139 \pm 53$ and $53 \pm 35 \mathrm{ml}$; in the group AH $2 \mathrm{nd}-135 \pm 42$ and $60 \pm 48 \mathrm{ml}$; in the group $\mathrm{AH} 3 \mathrm{rd}-132 \pm 39$ and $55 \pm 37 \mathrm{ml}$ ). Before the implantation ejection fraction of the left ventricle was below the norm in all hypertension groups. After the implantation, we observed it's increase to the standard value in all hypertension groups: in the group (AH 1st. $-62 \pm 15 \%$; in the group $\mathrm{AH} 2 \mathrm{nd}-57 \pm 13 \%$; in the group $\mathrm{AH} 3 \mathrm{rd}-57 \pm 10 \%$ ).

Thickness of the posterior wall of the left ventricular, posterior wall of left atrium, right ventricular and right atrium after the implantation remained unchanged in all groups, and probably require more time and effective medication support to stabilize.

The frequency of DDDR stimulation was the highest in all studied patients, with VVI, DDD, and VVIR stimulation modes occurring less frequently in descending order. The frequency of DDD and DDDR stimulation was the highest in groups of $\mathrm{AH} 1$ and 2 degree(without significant difference between the groups). VVI and VVIR stimulation was more frequent in hypertension group 3.

The proportion of different pacemaker modes in patients in the general sample and in the AH groups is presented in Fig 1. 


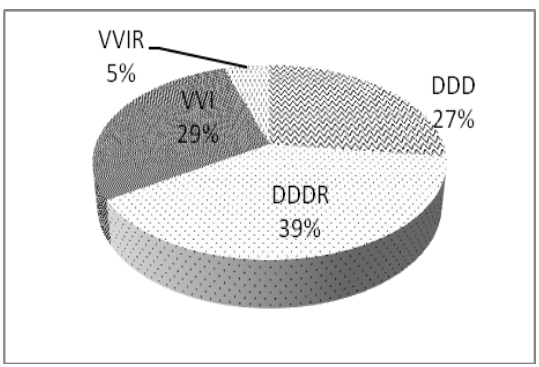

A

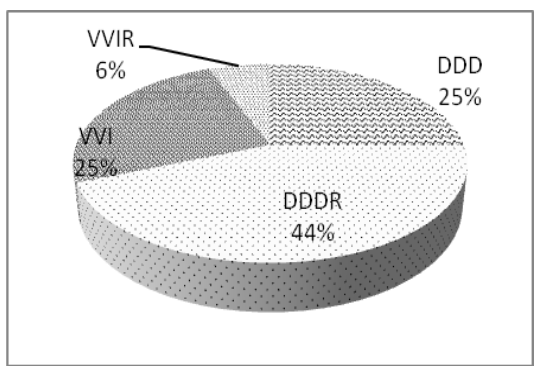

C

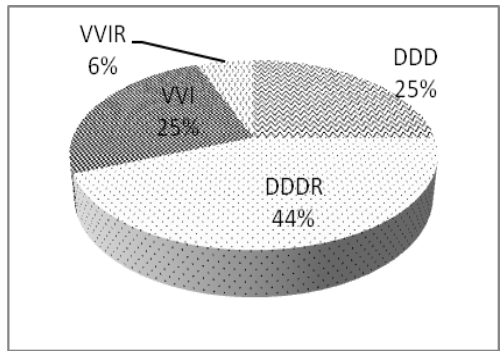

B

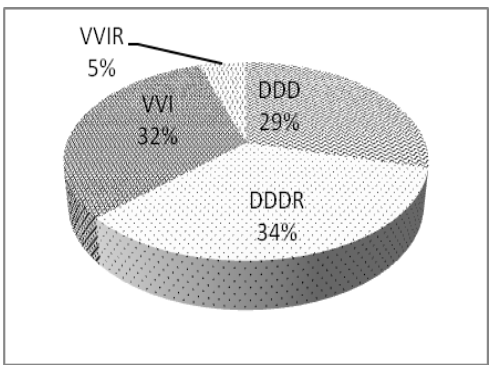

$\mathrm{D}$

Fig. 1. The proportion of different modes of the pacing: $A$ - in the total sample; $B$ - in group $\mathrm{AH}$ of $1^{\text {st }}$ degree; $\mathrm{C}$ - in group $\mathrm{AH}$ of $2^{\text {nd }}$ degree; $\mathrm{D}$ - in group $\mathrm{AH} 3^{\text {rd }}$ degree

The baseline stimulation rate averaged $66 \pm 7 \mathrm{bps} / \mathrm{min}$, and did not differ much between groups at all stages of post-implantation in DDD (R) / VVI (R) mode and pharmacotherapy, which positively affected the function of left ventricle regardless of stimulation mode.

There was no significant difference in the change of pacemaker parameters between DDD / DDDR and VVI / VVIR stimulation during the annual stage of maintenance drug therapy in patients with implanted pacemakers and suffering from hypertension. Nevertheless, there were higher parameters for VVI / VVIR stimulation.

It was noted that for DDD / DDDR stimulation mode, with the background of drug therapy in the early post-implantation period, the stimulation threshold and the ventricular electrode impedance were higher in the group of $\mathrm{AH} 3$ degree and lower in the group of $\mathrm{AH} 1$ degree. It gradually decreased in all groups during the annual period and on average decreased by $22 \%$. The AV-delay of the stimulated and detected complex in the early postoperative period was higher in the group of AH 3degree. At the 
annual monitoring stage with the medical management it increased by $20 \%$ for the groups of $\mathrm{AH} 2$ and 3 degree, and by 7\% in degree 1 group. The rate of ventricular stimulation increased in all groups at each stage of monitoring, and sought to $100 \%$ at the annual stage.

At the annual monitoring stage, VVI / VVIR stimulation with concomitant medication therapy was associated with a decrease in the threshold for stimulation and impedance of the ventricular electrode, with an average of $23 \%$ in all hypertension groups. The rate of ventricular stimulation increased at each stage of monitoring in all groups and sought to $100 \%$ at the annual stage of the study.

At the yearly stage of pacemaker and supportive drug therapy, the results showed an increase in the rate of stimulation in all groups of hypertension for DDD / DDDR and VVI / VVIR mode, with a tendency to decrease the impedance and the threshold for stimulation of right ventricle and left ventricle in all groups and for all stimulation modes. These changes indicate continued violations in the cardiac electrophysiology despite the optimization of pacing parameters and supporting drug therapy, which requires further improvement.

It was noted that at the annual stage of observation in $74 \%$ of patients in DDD / DDDR stimulation mode, to a greater extent at AH 2 and 3 degree, it was necessary to increase the AV-delay of the stimulated and detected complex. It was shown that in patients who required an increase in the AV-delay of the stimulated and detected complex, there was an increase in SBP by $9 \%$, and DBP by $5 \%$, which requires strengthening of antihypertensive therapy.

\section{Management of patients with arterial hypertension after implantation of cardiac pacemaker}

Prior to pacemaker implantation the following drugs were prescribed in descending order: antiagregants, ACE inhibitors, statins, Ca antagonists, diuretics, anticoagulants; less frequent: antiarrhythmic drugs, angiotensin-II receptor antagonist, which corresponds to the average data in this age group of patients. Pacemaker implantation at different stages increased the frequency of appointment and dose of anticoagulants, potassium channel blockers (amiodarone), diuretics, beta-adrenergic receptor blockers, angiotensin-II receptor antagonists and statins. The frequency of prescribing cardiovascular drugs in all patients before and at the annual stage after implantation of the pacemaker depending on the degree of hypertension is shown in Fig. 2. 


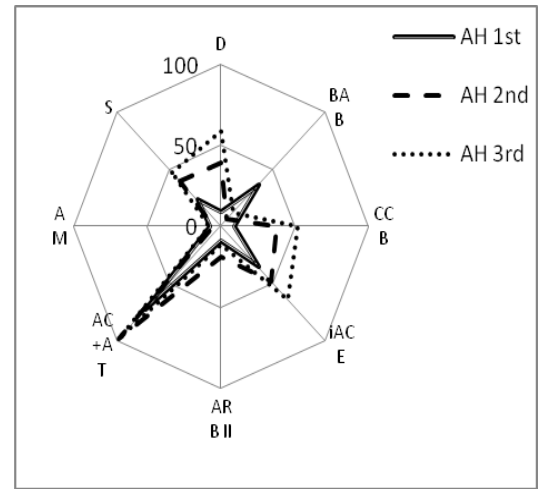

A

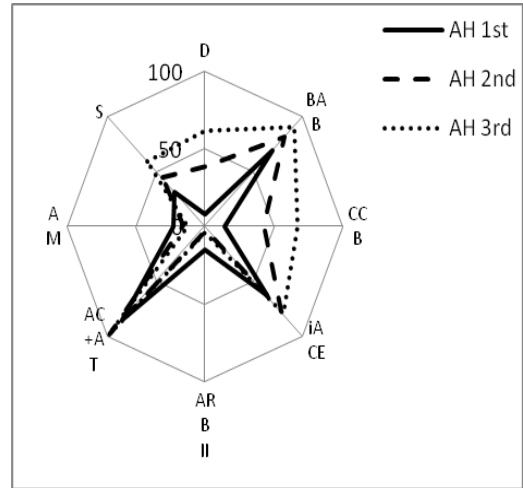

B

Fig. 2. Frequency of appointment of groups of anticoagulants (AC) andantiaggregant (AA) drugs, amiodarone (AM), diuretics (D), calcium channel blockers (CCB), beta-blockers (BAB), ACE inhibitors (iACE), antagonist II receptor blockers (ARB II) and statins (C) in patients before the implantation $(\mathrm{A})$ and after 1 year $(\mathrm{B})$ in groups of hypertension 1,2 and 3 degrees $(n, \% \pm p)$

The frequency of appointing major groups of antihypertensive drugs was determined by the degree of hypertension. According to the results of the yearly monitoring period, hypertension degree 3 required more frequent appointment of diuretics, $\mathrm{BAB}, \mathrm{Ca}$ antagonists and $\mathrm{ACE}$ inhibitors than degree 1 and 2 .

The dose of the major groups of antihypertensive drugs in patients with implanted pacemaker and hypertension was determined by the degree of hypertension, and at all stages of observation degree 3 required higher doses of $\beta$-blockers, ACE inhibitors, diuretics and antiarrhythmics than degree 1 and 2 .

Regardless of hypertension degree, an increase in the frequency of appointment of anticoagulants, antiagregants, HMG-CoA reductase inhibitors and antiarrhythmic drugs was required.

During the annual observation, pacemaker implantation and medication therapy positively affected the course of hypertension, which was manifested by a gradual increase in patients in the group oh $\mathrm{AH} 1$ degree, while the amount of patients with hypertension 2 nd and 3rd degree decreased and achievement of the target level of blood pressure in the all groups of patients. 
The incidence rates of patients in the $\mathrm{AH}$ groups, depending on the degree before and on the stages after implantation of cardiac pacemaker and drug therapy are presented in Fig. 3.

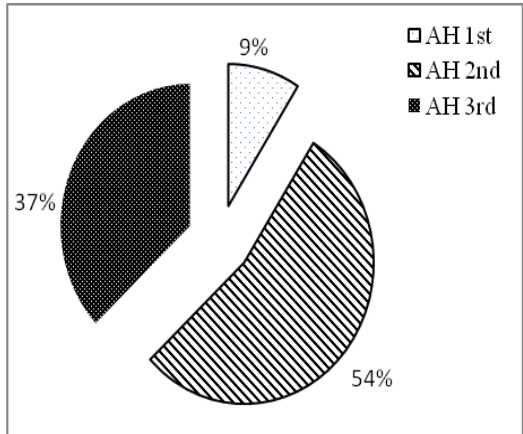

A

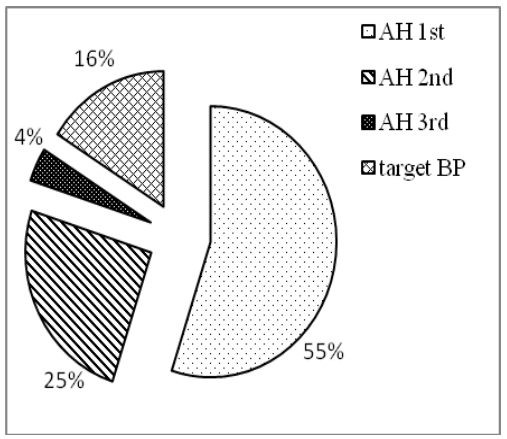

C

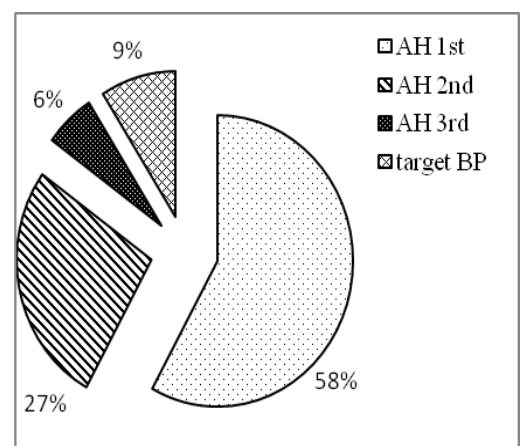

B

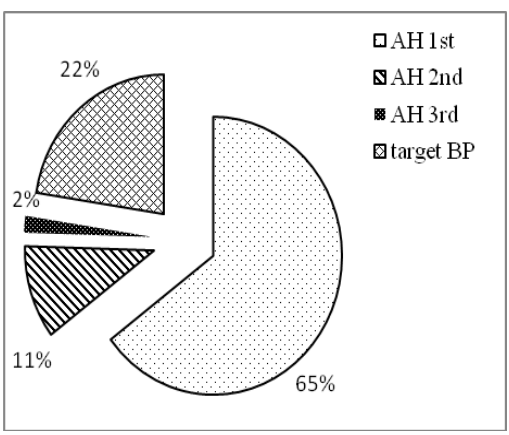

$\mathrm{D}$

Fig. 3. Patient incidence rates in the AH groups before (A), in the early postoperative period (B), at 6 months (C) and at 1 year (D) after implantation of the cardiac pacemaker

Table 1 presents the dynamics of blood pressure in patients with implanted pacemaker and $\mathrm{AH}$ at the annual stage after implantation and drugt herapy, depending on the degree of hypertension in DDD (R) mode.

Table 2 presents the dynamics of blood pressure in patients with implanted pacemaker and $\mathrm{AH}$ at the annual stage after implantation and drug therapy, depending on the degree of hypertension in VVI (R) mode. 
Table 1

The dynamics of blood pressure in patients with implanted pacemaker and $\mathrm{AH}$ at the annual stage after implantation and drug therapy, depending on the degree of hypertension in DDD $(R)$ mode

\begin{tabular}{|c|c|c|c|c|c|c|}
\hline \multirow{2}{*}{$\begin{array}{l}\text { Observation } \\
\text { period }\end{array}$} & \multicolumn{6}{|c|}{ Degree of AH } \\
\hline & \multicolumn{2}{|c|}{1 degree } & \multicolumn{2}{|c|}{2 degree } & \multicolumn{2}{|c|}{3 degree } \\
\hline \multirow{2}{*}{$\begin{array}{l}\text { Before the } \\
\text { implantation }\end{array}$} & SBP & $142 \pm 24$ & SBP & $161 \pm 17$ & SBP & $185 \pm 22$ \\
\hline & DBP & $91 \pm 9$ & DBP & $93 \pm 10$ & DBP & $99 \pm 8$ \\
\hline \multirow{2}{*}{$\begin{array}{l}3-5 \text { day after the } \\
\text { implantation }\end{array}$} & SBP & $135 \pm 11^{*}$ & SBP & $145 \pm 10$ & SBP & $160 \pm 11 *$ \\
\hline & DBP & $87 \pm 8$ & DBP & $88 \pm 9$ & $\mathrm{DBP}$ & $90 \pm 9$ \\
\hline \multirow{2}{*}{6 monthes } & SBP & $134 \pm 10$ & SBP & $142 \pm 12$ & SBP & $159 \pm 10$ \\
\hline & DBP & $84 \pm 8$ & DBP & $86 \pm 8$ & DBP & $88 \pm 8$ \\
\hline \multirow{2}{*}{ 1year } & SBP & $130 \pm 10^{\wedge}$ & SBP & $140 \pm 11$ & SBP & $154 \pm 11^{\wedge}$ \\
\hline & DBP & $81 \pm 7$ & DBP & $86 \pm 8$ & DBP & $88 \pm 7$ \\
\hline
\end{tabular}

Note: $* \mathrm{p}<0.05-$ between values in the groups of $1^{\text {st }}$ and $3^{\text {rd }} \mathrm{AH}$ in the acute period after implantation of the pacemaker; ${ }^{\wedge} \mathrm{p}<0.05-$ between the values in the groups of 1 st and $3 \mathrm{rd} \mathrm{AH}$ in 1 year after implantation of the pacemaker

Table 2

The dynamics of blood pressure in patients with implanted pacemaker and $\mathrm{AH}$ at the annual stage after implantation and drug therapy, depending on the degree of hypertension in VVI $(R)$ mode

\begin{tabular}{|l|c|c|c|c|c|c|}
\hline \multirow{2}{*}{$\begin{array}{l}\text { Observation } \\
\text { period }\end{array}$} & \multicolumn{6}{|c|}{ Degree of AH } \\
\cline { 2 - 7 } & \multicolumn{2}{|c|}{$\mathbf{1}$ degree } & \multicolumn{2}{c|}{ 2 degree } & \multicolumn{2}{c|}{ 3 degree } \\
\hline $\begin{array}{l}\text { Before the } \\
\text { implantation }\end{array}$ & SBP & $159 \pm 21$ & SBP & $160 \pm 24$ & SBP & $186 \pm 24$ \\
\cline { 2 - 7 } & DBP & $91 \pm 10$ & DBP & $94 \pm 10$ & DBP & $98 \pm 10$ \\
\hline $\begin{array}{l}3-5 \text { day } \\
\text { after the } \\
\text { implantation }\end{array}$ & SBP & $137 \pm 12^{*}$ & SBP & $148 \pm 11$ & SBP & $161 \pm 12^{*}$ \\
\cline { 2 - 7 } & DBP & $89 \pm 9$ & DBP & $89 \pm 8$ & DBP & $92 \pm 8$ \\
\hline \multirow{2}{*}{6 monthes } & SBP & $136 \pm 11$ & SBP & $148 \pm 12$ & SBP & $159 \pm 11$ \\
\cline { 2 - 7 } & DBP & $85 \pm 8$ & DBP & $87 \pm 8$ & DBP & $90 \pm 7$ \\
\hline \multirow{2}{*}{1 year } & SBP & $134 \pm 11$ & SBP & $142 \pm 10$ & SBP & $158 \pm 11$ \\
\cline { 2 - 7 } & DBP & $83 \pm 8^{\wedge}$ & DBP & $86 \pm 8$ & DBP & $89 \pm 7^{\wedge}$ \\
\hline
\end{tabular}

Note: $* \mathrm{p}<0.05-$ between values in the groups of 1 st and $3 \mathrm{rd} \mathrm{AH}$ in the acute period after implantation of the pacemaker; ${ }^{\wedge} \mathrm{p}<0.05-$ between the values in the groups of 1 st and $3 \mathrm{rd} \mathrm{AH}$ in 1 year after implantation of the pacemaker 
During the annual follow-up period, anti-hypertensive therapy in patients with DDD / DDDR stimulation had a significant decrease in SBP and DBP compared to VVI / VVIR, regardless of the degree of hypertension ( $p<0.05)$.

The results of step-by-discriminatory analysis established the increase in the weight factor in the AH of the 1 degree - for ACE inhibitors, in the AH of the 2nd degree - for ACE inhibitors and BRA II, in the AH 3 degree - for ACE inhibitors, BRA II and diuretics.The research showed a reduction in the weighting factor for systolic pressure and diastolic pressure, indicating the effectiveness of drug therapy.

In patients with implanted pacemakers, the most effective antihypertensive therapy was a combination of inhibitors of angiotensin converting enzyme or angiotensin II receptor blockers with slow calcium channel blockers; inhibitors of angiotensin converting enzyme or angiotensin II receptor blockers with diuretics, and triple antihypertensive therapy with inhibitors of angiotensin converting enzyme or angiotensin II receptor blockers with slow calcium channel blockers.

The table 3 presents certain factors that influence the achievement of the target level of blood pressure in patients with hypertension after implantation of the cardiac pacemaker, the results of a uni- and multi-variant log regression analysis, adjusted for the combination of antihypertensive drugs.

Table 3

Certain factors that influence the achievement of the target level of blood pressure in patients with hypertension after implantation of the cardiac pacemaker. The results of a uni- and multi-variant log regression analysis, adjusted for the combination of antihypertensive drugs

\begin{tabular}{|l|c|c|c|c|c|c|}
\hline \multirow{2}{*}{ Indicators } & \multicolumn{3}{|c|}{ Univariant } & \multicolumn{3}{c|}{ Multivariant } \\
& \multicolumn{2}{|c|}{ logregressionanalysis } & \multicolumn{2}{c|}{ logregressionanalysis } \\
\cline { 2 - 7 } & VS & MKI & P & VS & MKI & P \\
\hline BiK > 65 років & 0.86 & $0.77-0.95$ & 0.012 & 0.89 & $0.80-0.98$ & 0.04 \\
\hline DDD mode & 1.05 & $1.02-1.09$ & 0.02 & 1.05 & $1.01-1.10$ & 0.044 \\
\hline DDDR mode & 1.04 & $1.01-1.09$ & 0.04 & 1.07 & $1.02-1.11$ & 0.035 \\
\hline VVImode & 1.02 & $0.98-1.06$ & 0.66 & - & - & - \\
\hline VVIR mode & 1.01 & $0.98-1.07$ & 0.82 & - & - & - \\
\hline DM & 0.85 & $0.73-0.97$ & 0.001 & 0.86 & $0.78-0.95$ & 0.01 \\
\hline iACE & 1.07 & $1.03-1.11$ & 0.001 & 1.05 & $1.03-1.08$ & 0.01 \\
\hline BRA II & 1.05 & $1.03-1.08$ & 0.01 & 1.04 & $1.02-1.06$ & 0.02 \\
\hline CCB & 1.08 & $1.04-1.10$ & 0.024 & 1.05 & $1.02-1.09$ & 0.034 \\
\hline BAB & 1.02 & $0.99-1.04$ & 0.72 & - & - & - \\
\hline Diuretics & 1.04 & $1.01-1.07$ & 0.046 & 1.03 & $1.01-1.05$ & 0.048 \\
\hline
\end{tabular}


The factors that influence on the achievement of adequate control of blood pressure levels in patients with hypertension (with the exception of the combination of ACE or BRA II with Ca-chanel blockers and ACE or BRA II with diuretic) were found to be the most significant factors: DDD stimulation mode $(\mathrm{VS}=1.05 ; \mathrm{P}=0.044) ; \quad \mathrm{DDDR}$ stimulation mode (VS $=1.07 ; \quad \mathrm{P}=0.035)$, as well as the appointment of ACE-inhibitors (VS $=1.05 ; \mathrm{P}=0.01)$, BRA II $(\mathrm{VS}=1.04 ; \mathrm{P}=0.02)$, Ca-chanel blockers $(\mathrm{VS}=1.05 ; \mathrm{P}=0.034)$ and diuretics $(\mathrm{VS}=1.03 ; \mathrm{P}=0.048)$.

According to the obtained data, clinical and hemodynamic indices are important criterias for predicting the results of medical intervention in patients with implanted pacemakers, taking into account the hypertension degree.

The practical significance of the results is justified by the necessity of implantation of a two-chamber pacemaker in the mode of DDDR stimulation in patients with arterial hypertension. In the therapeutic support of patients with arterial hypertension after the implantation of cardiac pacemaker, requiring an increase in $\mathrm{AV}$-delay, it is recommended to increase antihypertensive therapy by adding slow-acting calcium channel blockers. In the early postoperative period (3-5 days after implantation), patients with arterial hypertension regardless of degree of arterial hypertension, it is recommended to double the frequency of appointment and doses of betablockers, angiotensin-converting enzyme.

\section{CONCLUSIONS}

At the annual stage after implantation of the pacemaker in patients with hypertension, optimization of drug therapy helps to reduce systolic and diastolic blood pressure, decreases end-systolic and end-diastolic volumes, increases the ejection fraction.

Correction of antihypertensive therapy at the annual stage of observation in all groups of hypertension after implantation of cardiac pacemaker contributes to the reduction of threshold and impedance of ventricular stimulation. At the annual observation stage, $74 \%$ of patients with 2 and 3 degree of hypertension require a $20 \%$ increase in AV delay. On the background of medication, DDDR stimulation contributes to a reduction in systolic and diastolic blood pressure, significantly.

Implantation of cardiac pacemaker with an increase in the degree of arterial hypertension in the acute period (3-5 days after implantation) requires an increase in the frequency of appointment of beta-blockers, inhibitors of angiotensin-converting enzyme, and in the long term diuretics, inhibitors of angiotensin converting enzyme and renin-angiotensin II receptor blockers, as well as increasing the dose of slow calcium channel blockers and diuretics, to a greater extent with 3 degree of hypertension.

In the therapeutic management of patients with hypertension after implantation of the pacemaker who require an increase in AV-delay, it is 
recommended to increase antihypertensive therapy by adding slow calcium channel blockers.

In the early postoperative period (3-5 days after implantation), patients with arterial hypertension, regardless of the degree of hypertension, it is recommended to double the frequency and dose appointmentof beta-blockers and inhibitors of angiotensin-converting enzyme.

In patients with implanted pacemakers, the most effective antihypertensive therapy is a combination of inhibitors of angiotensin converting enzyme or angiotensin II receptor blockers with slow calcium channel blockers; inhibitors of angiotensin converting enzyme or angiotensin II receptor blockers with diuretics, and triple antihypertensive therapy with inhibitors of angiotensin converting enzyme or angiotensin II receptor blockers with slow calcium channel blockers and diuretics.

\section{SUMMARY}

This article is devoted to establish the characteristics of changes in the degree of arterial hypertension (AH) and their importance in pharmacological support of patients with permanent pacemakers.

Before the implantation 1degree $\mathrm{AH}$ was found in 9\%, 2 degree $\mathrm{AH}$ - in $54 \%, 3$ degree $\mathrm{AH}-$ in $37 \%$. At the annual stage of pacing, optimization of medical therapy contributed to an increase in the concentration of patients in the group of 1degree of $\mathrm{AH}$, due to reduction in groups 2 and 3 degree of $\mathrm{AH}$ and achievement of the target level of BP in the group of patients.

At the annual stage, after the implantation of cardiac pacemaker in patients with $\mathrm{AH}$, optimization of drug therapy contributed to a decrease in systolic blood pressure (SBP) and diastolic systolic blood pressure (DBP), a decrease in the end systolic and diastolic volume and an increase in ejection fraction of $\mathrm{LV}$.

It was noted that at the annual stage of observation in $74 \%$ of patients in DDD / DDDR stimulation, it was necessary to increase the AV-delay of the stimulated and detected complex, to a greater extent at AH 2 and 3 degree. It was shown that in patients who reqiredan increase in the AV-delay of the stimulated and detected complex, there was an increase in SBP by 9\%, and DBP by 5\%, which requires strengthening of antihypertensive therapy.

During the annual follow-up period, anti-hypertensive therapy in patients with DDD / DDDR stimulation had a significant decrease in SBP and DBP compared to VVI / VVIR, regardless of the degree of hypertension.

\section{REFERENCES}

1. Шанина И.В., Волков Д.Е., Бойко В.В., Яблучанский Н.И. Постоянная электрокардиостимуляция и медикаментозное сопровождение пациентов. Серие I Судини. 2014. № 2(46). С. 91-95. 
2. Brignole, M. et al. ESC Guidelines on cardiac pacing and cardiac resynchronization therapy. European Heart Journal. 2013. № 34(29). C. 2281-2329.

3. Бокерия Л., Ревишвили А., Голицин С. Всероссийское научное общество специалистов по клинической электрофизиологии, аритмологии и кардиостимуляции (BНОА). Клинические рекомендации по проведению электрофизиологических исследований, катетерной абляции и применению имплантированных антиаритмических устройств. Новая Редакция. 2013.

4. Tracy, C., Epstein, A., Darbar, D., DiMarco, J., Dunbar, S., Estes, N. et al. 2012 ACCF/AHA/HRS Focused Update of the 2008 Guidelines for Device-Based Therapy of Cardiac Rhythm Abnormalities: A Report of the American College of Cardiology Foundation/American Heart Association Task Force on Practice Guidelines and the Heart Rhythm Society. Circulation. № 126(14). 2012. P. 1784-1800.

5. Buess, D., Giezendanner, S., Henny-fullin, K., Handschin, A., Tschudi, P., Martina, B. et al. Compliance with ESH/ESC guidelines for arterial hypertension in Swiss primary care. Journal Of Hypertension. 34. 2016: e73-e74.Stefanadis, S. Management of arterial hypertension: from no treatment to renal denervation. Hellenic J Cardiol. 2015. P. 8-277.

6. Лазебник Л., Комисаренко И. Артериальная гипертония и сопутствующие заболевания. В Мире Лекарств. 2000. № 3. С. 20-26.

7. Elango K., Curtis A.B.. Cardiac implantable electrical devices in women ClinCardiol. Epub. 2018. № 41(2). P. 232-238.

8. Peinado, R., Ruiz-Mateas, F., Izquierdo, M., Arana, E., Robledo, M., Arias, M. et al. Cardiac Arrhythmias and Pacing 2015: A Selection of Topical Issues. Revista Española De Cardiología (English Edition). 2016. № 69(2). P. 167-175.

9. Wilkoff BL, et al. 2015 HRS/EHRA/APHRS/SOLAECE expert consensus statement on optimal implantable cardioverter-defibrillator programming and testing. EP Europace. 2017. № 19(4). P. 580-580.

10. Kusumoto, F., Goldschlager, N. Cardiac pacing for the clinician. NewYork : Springer, 2008. P. 30-742.

11. Coma Samartín, R., Ruiz Mateas, F., Fidalgo Andrés, M., Leal delOjo González, J., Pérez Álvarez, L. Spanish Pacemaker Registry. $10^{\text {th }}$ Official Report of the Spanish Society of Cardiology Working Group on Cardiac Pacing (2012). RevistaEspañolaDeCardiología (EnglishEdition). 2013. № 66(12). P. 72-972.

12. Naqvi T. The next 10 years in cardiac pacing. Expert Review Of Cardiovascular Therapy. 2013. № 11(7). P. 807-809.

13. Бокерия Л., Ревишвили А., Гордеев О. Клинические рекомендации по применению электрокардиостимуляторов. Вестник Аритмологии. 2009. № 58. С. 60-79. 
14. Lang, R., Bierig, M., Devereux, R., Flachskampf, F., Foster, E., Pellikka, P. et al. Recommendations for Chamber Quantification: A Report from the American Society of Echocardiography's Guidelines and Standards Committee and the Chamber Quantification Writing Group, Developed in Conjunction with the European Association of Echocardiography, a Branch of the European Society of Cardiology. Journal Of The American Society Of Echocardiography. 2005. № 18(12). C. 1440-1463.

15. Janson C., Shah M. Supraventricular Tachycardia in Adult Congenital Heart Disease. Cardiac Electrophysiology Clinics. 2017. № 9(2). C. $189-211$.

16. Рекомендації Української Асоціації Кардіологів з профілактики та лікування артеріальної гіпертензії (2011 рік). WebCardio.org. 2011. URL: http://www.webcardio.org/rekomendatsiji-ukrajinsjkoji-asotsiatsijikardiologhiv--z-profilaktiki-ta-likuvannya-arterialjnoji-ghipertenziji-2011rik.aspx.

17. Mancia, G., Fagard, R., Narkiewicz, K., Redán, J., Zanchetti, A., Böhm, M. et al. 2013 Practice guidelines for the management of arterial hypertension of the European Society of Hypertension (ESH) and the European Society of Cardiology (ESC). Journal Of Hypertension. 2013. № 31(10). C. 1925-1938.

18. Tracy, C., Epstein, A., Darbar, D., DiMarco, J., Dunbar, S., Estes, N. et al. 2012 ACCF/AHA/HRS Focused Update of the 2008 Guidelines for Device-Based Therapy of Cardiac Rhythm Abnormalities: A Report of the American College of Cardiology Foundation/American Heart Association Task Force on Practice Guidelines and the Heart Rhythm Society. Circulation. 2012. № 126(14). C. 72-959.

Information about authors: Deriyenko T. A.,

Candidate of Medical Sciences, Assistant Professor at the Department of Internal Medicine V. N. Karazin Kharkiv National University 4, Svobody Sq., Kharkiv, 61022, Ukraine

Tykhonova T. M., MD, Doctor of Medical Sciences, Professor, Head of the Department of Internal Medicine V. N. Karazin Kharkiv National University 4, Svobody Sq., Kharkiv, 61022, Ukraine 